(C) С.В. Грозовская

\title{
ГОРОДСКАЯ МОРФОЛОГИЯ ИСТОРИЧЕСКИХ ЦЕНТРОВ САМАРЫ И ТБИЛИСИ И ПРАКТИКИ СОЦИАЛЬНОГО ВЗАИМОДЕЙСТВИЯ ЖИТЕЛЕЙ
}

В статье анализируется взаимосвязь морфологии исторических кварталов Самары и Тбилиси серединь XX-начала XXI века с практиками сочиального взаимодействия их жителей. Для этого применяется концепция «городской деревни» («Urban village»), теория городской морфологии и теория фреймов. Мы показываем, какие маркеры городской среды подталкивают жителей к активному общению с соседями, а какие препятствуют этому. Исследование основано на полевых материалах автора, собранных в 2016-2020 годах в рамках проекта регенерации квартала № 13 в историческом ицентре Самары, пространственном анализе морфологии и включённом наблюдении, проведённых в 2016-2018 годах в Тбилиси и Самаре. Жители исторических иеетров Тбилиси и Самары фреймируют пространство дворов как частно-публичное, продолжающее дом/квартиру. Жители присваивают себе пространство двора, но в то же время разделяют его с соседями. Двор осмысляется резидентами какместо коммуникации и взаимодействий, что обуславливает их практики совместного времяпрепровождения и общения. Приватные и публичные пространства в самарских двориках располагают к совместной деятельности, а публичные пространства в тбилисских двориках - к общению. Маркеры, благодаря которыл жители фреймируют двор как частно-публичное пространство, - относительно небольшое число жителей; небольшой размер двора; наличие старожилов; малая и/или средняя этажность; наличие старых домов. Для Тбилиси ешее очень важны галереи, террасы и балкончики, объединяюшие обитателей нескольких квартир, плотная периметральная застройка, а для Самары - возможность фрагментации границ дворов. Чем большее число маркеров утрачивается, тем сильнее ослабляются практики совместных действий.

Ключевые слова: городская морфология, культурные практики, городские сообщества, сочиальное взаимодействие жителей, городская деревня, историческая среда, дворы

Ссылка при цитировании: Грозовская С.В. Городская морфология исторических центров Самары и Тбилиси и практики социального взаимодействия жителей // Вестник антропологии, 2022. № 1. С. 84-103.

Грозовская Снежана Владимировна - аспирант кафедры Инновационного проектирования, Самарский государственный технический университет Академии строительства и архитектуры (443100 Самара, ул. Молодогвардейская, 194). Эл. почта: snezhana.lashchenko@gmail.com 
(C) S.V. Grozovskaya

\title{
URBAN MORPHOLOGY OF THE HISTORICAL CENTERS OF SAMARA AND TBILISI AND THE SOCIAL INTERACTION OF THEIR RESIDENTS
}

\begin{abstract}
The article analyzes the relationship between the historical morphology of Samara and Tbilisi and the social interaction of their residents from the middle of the XX to the early XXI century. To do so, the author applies the concept of "Urban village», the theory of urban morphology, and the theory of frames. Frame analysis highlights the markers of the urban environment that prompt residents to communicate with their neighbors actively and those that hinder this communication. The study is based on the fieldwork in Samara in 2016-2020, spatial analysis of morphology, and participant observation carried out in 2016-2018 in Tbilisi and Samara. Residents of the historical centers of Tbilisi and Samara frame the space of courtyards as privatepublic, continuing the houselapartment. They own this space, but at the same time, they share it with their neighbors. Residents understand the courtyard as a place of interaction, which defines their joint pastime and communication. Private and public spaces in Samara courtyards invite for joint activities, and Tbilisi courtyards encourage communication. Residents frame the courtyard as a public-private space through some markers that include a relatively small number of residents; the small size of the courtyard; the presence of old-timers; the low or medium number of floors; the presence of old houses. In Tbilisi, neighbors come together in galleries, terraces, and balconies. The density of buildings is also substantial for communication. The possibility to fragment the boundaries of courtyards is significant for Samara. The more markers are lost, the weaker the practices of joint activities become.
\end{abstract}

Keywords: urban morphology, cultural practices, urban commons, residents 'social interaction, urban village, historical environment, courtyards

For Citation: Grozovskaya, S.V. 2022. Urban Morphology of the Historical Centers of Samara and Tbilisi and the Social Interaction of their Residents. Herald of Anthropology (Vestnik Antropologii) 1: 84-103.

Author Info: Grozovskaya, Snezhana V. - postgraduate student of the Department of Innovative Design, Samara State Technical University of the Academy of Civil Engineering and Architecture (Samara, RF), E-mail: snezhana.lashchenko@gmail.com.

Современная картина российских городов выглядит так: в советских и постсоветских микрорайонах живёт примерно три четверти городских жителей. Такие жилые кварталы имеют площадь от 5 до 60 га. Огромные «ничейные» пространства между домами не способствуют возникновению сообществ и появлению у жителей желания обживать, обустраивать эти пространства из-за их «необъятности». Дворы являются общественными, они принадлежат «всем и никому». В одном дворе с многоэтажными домами может жить 500-2000 человек (со среднеэтажными - порядка 200-400 чел.). 
Очевидно, что такое число соседей не может «присвоить» себе общее пространство.

Сообщества жителей не складываются здесь как в силу морфологии этих районов, так и потому, что в них довольно быстрая ротация резидентов («старожилы» растворяются среди новых жителей) (Vihavainen 2009). Объединиться во временные сообщества жителей таких микрорайонов заставляет лишь «внешняя угроза» (вырубка парка, снос дома), а также (в значительно меньшей степени) проекты пе-

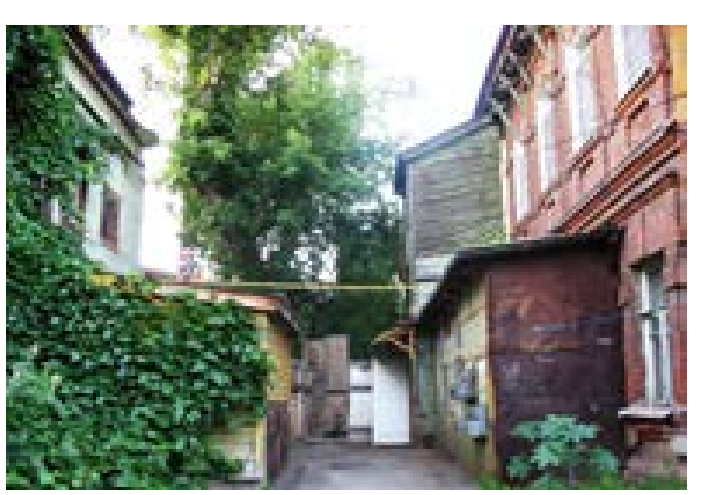

Рис. 1. Фрагмент дворика в цеентре Самары (фото автора, исторический иентр Самары, 2016).

Fig. 1. A courtyard in the old center of Samara (photo by the author, historical center of Samara, 2016). репланировки и благоустройства дворов. Исключением из этого правила стали лишь появившиеся в 2010-х гг. новые микрорайоны, куда жители заселяются одновременно и при помощи соцсетей объединяются в сообщества уже на этапе строительства дома (а тем более - после заселения). Такие сообщества помогают «переселенцам» решать общие для них жилищно-коммунальные проблемы (Peген 2019), возникают горизонтальные практики взаимопомощи и заботы об окружающем пространстве.

Другой тип морфологии постсоветского городского пространства - кварталы с дореволюционной застройкой - занимает лишь малую часть территорий городов и представляет собой особую пространственную, культурную и социальную ткань. В «получастных» дворах исторических центров Тбилиси и Самары с

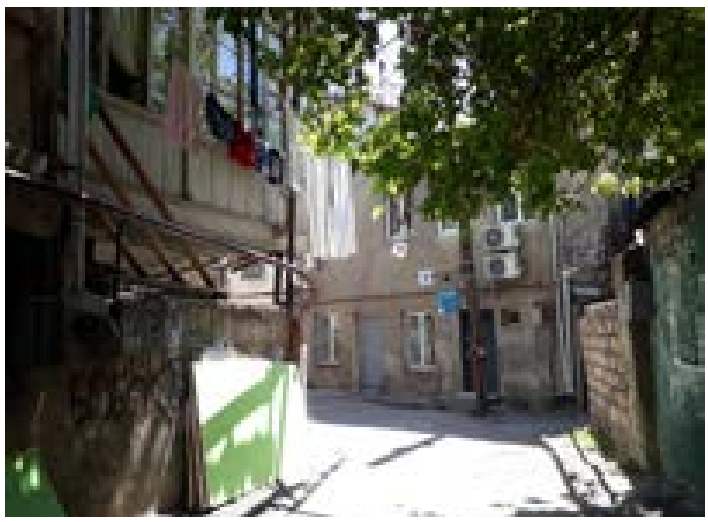

Рис. 2. Узкая улочка в старом иентре

Тбилиси (фото автора, старый ичентр Тбилиси, 2017).

Fig. 2. A narrow street in the old center of Tbilisi (photo by the author, old center of Tbilisi, 2017). малоэтажной застройкой обитает примерно 15-40 чел. (6-13 семей). При таком типе застройки жители расположены к более плотному взаимодействию как с самим пространством, так и друг с другом благодаря небольшому числу резидентов (среди которых выделяются старожилы) и наличию компактных двориков с мало- и среднеэтажной застройкой. Такие сообщества постоянны и укоренены в физическом пространстве. Тем не менее, жители других районов зачастую воспринимают их как маргинализированные, неблагополучные, да и в самой городской среде исторического центра, состоящей из старых домов, не видят ничего привлекательного.

В последние годы жители постсоветских городов начинают осознавать своё право на город и объединяться в сооб- 
щества для совместных действий в острых ситуациях (Андреев 2019, Перцев 2019), они стали лучше соорганизовываться для защиты своих интересов (Панеях 2018). Однако практики соорганизации горожан все еще распространены не слишком широко (Медведев 2017, Желнина, Тыканова 2019), даже в ситуации, когда их интересы сильно затронуты (Иванов 2014, Кузнецова 2017). Вместе с тем еще недавно (в середине XX века) в исторических центрах советских городов существовали районные и дворовые сообщества с сильной идентичностью, для которых соорганизация не была проблемой (Пиир 2006).

Эта статья сфокусирована на изучении морфологии и культурных практик исторических центров Тбилиси и Самары. Советская политика повлияла на городскую ткань исторических центров городов, социальные и культурные практики их обитателей. Коммунальный опыт и заселение дворов с исторической застройкой новыми жителями и стимулированный советской властью рост городов, переселение в них деревенских жителей наделили центры Тбилиси и Самары сходными чертами. В них существуют местные сообщества жителей, объединенные общим физическим пространством проживания (двором, домом, улицей, кварталом), которое они совместно обживают и разделяют между собой. Морфология этих пространств имеет общие черты: старую мало- и среднеэтажную застройку, многоквартирные дома с общими полуприватными двориками, множество архитектурных элементов (балкончики, веранды, галереи, наружные лестницы и т.п).

Похожесть старым кварталам Тбилиси и Самары придаёт небольшое число жителей во дворах. Морфология пространства во многом обуславливает характер взаимодействия резидентов и образ жизни. Взаимосвязь таких морфотипов с укоренёнными в них сообществами характерна для «городских деревень» («urban villages»), к которым относятся исторические центры Тбилиси и Самары (Лащенко 2020). Власти обоих городов выделяют недостаточно средств на реставрацию и восстановление исторических зданий, поэтому старые центры Тбилиси и Самары, поддерживаемые в основном жителями, ветшают и разрушаются.

В то же время у этих городов есть существенные отличия. Их жители по-разному относятся к историческому наследию. Самарцы пренебрегают историческими домами, дворами, считая их непригодными для существования. Тбилисцы наоборот ценят историческое наследие и тесно связывают с ним свою идентичность. Благодаря этому в Тбилиси, несмотря на скудное финансирование восстановления старого города, сохраняется его целостность и непрерывность морфологии. А в Самаре недостаток средств на реконструкцию усугубляется безразличием к наследию жителей и политикой властей, поддерживающей инициируемые застройщиками сносы и прибыльную застройку. Это сильно разрушает морфологию пространства.

Тбилиси - пример постсоветского города с сохранившейся целостной тканью хаотичной средневековой планировки, а в некоторых районах регулярной, в которую местами органично вписаны новые здания (в небольшом количестве), учитывающие параметры старых. Исторический центр Самары - пример постсоветского города с регулярной планировкой, где еще остались целостные фрагменты исторической морфологии, но есть и множество кварталов, частично или целиком разрушенных высотной застройкой, не учитывающей контекст.

Сравнение этих городов позволяет увидеть, что несмотря на различные культурные, социальные и политические контексты, сходные черты физического пространства и 
опыт советской политики создают похожие культурные практики и паттерны поведения жителей. Разные политики развития этих городов влияют на возможность сохранения/утраты таких практик. Благодаря морфологии застройки и образу жизни в таких кварталах развиты горизонтальные связи, жителей объединяют совместные действия и практики времяпрепровождения. Они, в свою очередь, формируют социальный капитал и общую идентичность. Исследование способов социального взаимодействия жителей «городских деревень», их культурных практик позволяет понять механизмы их формирования, которые могут использоваться в современной градостроительной политике, практиках поддержки городских сообществ и развития территорий.

Почему в одних районах, кварталах и дворах жители отчуждены друг от друга, а в других почти все со всеми знакомы? Отчего в одних дворах жители проводят много времени вместе, а в других почти не пересекаются? В связи с чем в одних городах «городские деревни», существовавшие в начале-середине XX века, сегодня быстро умирают, а в других их жизнь поддерживается? Эти вопросы мы ставим применительно к двум очень разным городам - историческим кварталам Самары и Тбилиси середины XX - начала XXI вв.

\section{Теоретические рамки}

В этом исследовании мы опираемся на ряд теоретических разработок, в том числе городского теоретика, активиста и журналиста Джейн Джекобс, которая называла повседневные взаимодействия соседей, владельцев магазинов и незнакомцев в старых кварталах Гринвич-Виллиджа в Нью-Йорке «уличным балетом» (Джекобс 2011). Такие взаимодействия возникают в компактной, малоэтажной застройке, где резиденты знают друг друга и обживают физическое пространство, создавая в нём маленькие семейные магазинчики, кафе, мастерские. Возникают социальные связи, ведущие к образованию «городских деревень», где сильны соседские сообщества, объединенные многообразными практиками взаимодействия.

Появление в этих районах элитного жилья и джентрификация ведут к разрушению сообществ и преемственности культурных практик, показывает профессор Городского университета Нью-Йорка Шарон Зукин (Зукин 2019). К тому же эффекту приводит вкрапление высотной застройки в старые кварталы. Концепция «городской деревни» позволяет нам идентифицировать пространство двора в историческом квартале как место, в котором городские сообщества и их культурные практики укоренены в исторически сложившейся морфологии (Gans 1962). Зафиксировать различия в организации пространства дворов, кварталов и районов, в которых живут люди в городах, позволяет теория городской морфологии. (Larkham 2018, Sadeghi, Li 2019). Она показывает, что морфотипы городских пространств формируются такими физическими параметрами, как планировка кварталов, тип и плотность застройки, ширина улиц, размер и форма участков (дворов), этажность, архитектурные элементы зданий, материалы и др. (Oliveira 2016), а само пространство может быть не только частным или публичным, но и смешанным (Nissen 2008).

Каким же образом городская морфология определяет культурные практики жителей? Для ответа на этот вопрос мы используем теорию фреймов. Фрейм («рамка», «кадр») - это способ восприятия и понимания ситуации её участниками (Гофман 2003, Яноу, Ван Хульст 2011). В нашем случае «ситуацией» является архитектурное 
пространство двора/квартала/микрорайона, а участниками - их резиденты. Фреймируя ситуацию, люди наделяют ее отдельные признаки значением (и в результате трактуют всю ситуацию тем или иным образом), регулируя в соответствии с этим фреймом свое поведение (Blumer 1969). Фреймирование преобразует контекст, позволяя сделать одни его детали заметными, а другие - «невидимыми». Эта теория приложима и к городским исследованиям (Вахштайн 2007): жители «замечают» отдельные элементы городской морфологии, а затем сами эти элементы, в соответствии с приобретённым ими смыслом, влияют на поведение резидентов. Так возникают характерные для различных пространств культурные практики. Совокупно концепт «городской деревни», теория городской морфологии и теория фреймов позволяют описать, какие именно элементы городской среды становятся для жителей маркерами, позволяющими фреймировать городское пространство тем или иным образом и строить в соответствии с этим свое поведение.

Какие именно маркеры физического пространства становятся для жителей определяющими в плане фреймирования городской среды как располагающей или не располагающей к соседским социальным взаимодействиям? Новизна настоящего исследования состоит в применении теории фреймов к анализу взаимосвязи морфологии исторических кварталов и практик социального взаимодействия их жителей. Теория фреймов позволяет показать, какие именно маркеры городской среды подталкивают жителей к активному общению с соседями, характерному для «городской деревни», а какие препятствуют этому. Мы ставим цель показать, что одни маркеры способствуют фреймированию двора как части микрорайонной застройки («общее» и «ничье» пространство), где взаимодействие между жителями сведено практически к нулю. Другие маркеры позволяют фреймировать двор как часть компактной квартальной застройки, где двор - полуприватное пространство, подталкивающее резидентов к активному взаимодействию друг с другом. Нам также интересно проследить, как менялись эти маркеры на протяжении середины XX - начала XXI в.

\section{Исследовательские задачи, гипотеза, методы}

Исследовательский вопрос состоит в том, какие маркеры морфологии исторических кварталов/дворов Самары и Тбилиси на протяжении середины XX - начала XXI в. способствовали социальным взаимодействиям жителей, а какие - препятствовали. Мы проверим следующие гипотезы. 1) При наличии достаточного числа маркеров «городской деревни» практики социального взаимодействия воспроизводятся. При уменьшении их числа практики становятся менее интенсивными, а некоторые угасают. Когда маркеров становится еще меньше, наиболее значимые культурные практики исчезают. 2) Основные маркеры, влияющие на фреймирование квартала/ двора - этажность застройки, размер двора, число жителей, наличие старожилов.

Для ответа на исследовательский вопрос выделим маркеры городского пространства в исторических кварталах/дворах Самары и Тбилиси середины XX - начала XXI в., которые влияют на их фреймирование и тем самым на практики взаимодействия жителей. Затем мы проанализируем, какие маркеры морфологии оказываются ключевыми для такого фреймирования (и сохранения таких практик), а какие - факультативными.

Исследование базируется на полевых материалах автора, собранных в Самаре и Тбилиси в период 2016-2020 гг. Часть материалов получена автором в рамках проекта 
регенерации квартала №13 в историческом центре Самары в составе исследовательской группы Института города Самары и Академии строительства и архитектуры (АСА СамГТУ) в 2016 г., тогда был проведён опрос 80 жителей квартала (что составляет примерно 90\% дворов). В Самаре также собраны автором 18 полуструктурированных глубинных интервью с резидентами исторического центра в 2019-2020 г. (информанты выбраны рандомно). В Тбилиси в 2017 г. и Самаре в 2016, 2019 и 2020 г. применён метод включённого наблюдения и проведён пространственный анализ морфологии.

\section{Самара}

Центр Самары имеет регулярный екатерининский план 1782 г. на основе прямоугольной сетки с кварталами размером 260х130 м., изначально разделёнными на 20 дворовладений (городских усадеб). Городская усадьба была в частной собственности и состояла из малоэтажных деревянных, каменно-деревянных и каменных домов, флигелей, построек для слуг, мастерских, помещений для торговли и хранения товаров. Со временем дворы уплотнялись: дома перестраивались, возникали новые постройки, некоторые квартиры и комнаты сдавались хозяином внаём (Schiemann etc 2020).

С приходом советской власти дома и вспомогательные строения превратились в коммунальные квартиры, в которые переехали жители из деревень и малых городов; там же могли продолжать жить прежние хозяева усадеб (Малахов 2009). Бывшие жители деревень привнесли в городские кварталы некоторые деревенские практики. К ним можно отнести соседское общение во дворах и на улицах, совместные игры и уличные застолья, практики взаимопомощи, обустройство и «достраивание» домов, выращивание овощей, цветов, фруктовых садиков, устройство палисадников во дворах и рядом с ними, разведение мелких животных: «За забором голосил петух, а в небе под свист Мишки-голубятника кружили белые турманы» (Мишин 2014). Многие из этих практик до сих пор сохранились и были зафиксированы нами в ходе полевых исследований.

Внутреннюю структуру самарских двориков определяют такие маркеры, как

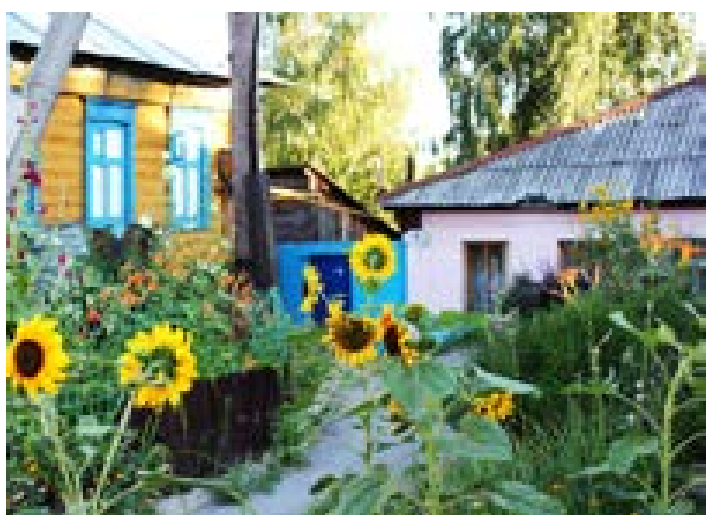

Рис. 3. Жители выращивают палисадники напротив своих домов (фото автора, исторический центр Самары, 2016).

Fig. 3. Locals plant gardens in front of their houses (photo by the author, the historical center of Samara, 2016). планировка квартала (деление на небольшие участки/дворы и возможность их дальнейшей фрагментации), низкая и средняя плотность застройки, размер двора (ширина приблизительно 10,5/21/30 м., а глубина - 30/50 м.), форма двора. За счет дворов жители часто компенсировали «коммунальную тесноту». Компактные, но довольно просторные, со свободным пространством и сложными пространственными формами-лабиринтами, они позволяют укрыться от активной жизни города. Деление кварталов на маленькие участки становится для жителей сигналом, что это пространство можно осваивать, делать его «обитаемым» под свои нуж- 
ды. Планировка двора даёт им возможность продолжить и расширить пространство своей квартиры за счет достраивания домов, создания малых архитектурных форм.

Границы дворов в меру подвижны: жители могут дробить пространство двора, деля территорию на несколько частей. Форма, размер и возможность фрагментации двора позволяют фреймировать это пространство как частно-публичное. Жители и в советское, и в постсоветское время ощущают себя хозяевами этого пространства, однако законодательно оно не является частным.

Такому фреймированию пространства способствуют и архитектурные элементы домов (террасы, балконы, галереи), возникающие в процессе приспособления жителями дворов этого пространства под свои потребности. Внутри общего с соседями пространства возникают приватные объекты и фрагменты. Жители пристраивают индивидуальные входы в квартиры, лестницы, веранды, террасы, строят галереи и другие помещения: «Терраса была универсальным пространством: в жаркие летние ночи мы перебирались туда с раскладушками, в дождь там хорошо игралось в бильярд с железными шарами, карты или шахматы. Первая сигарета, липкий стакан портвейна, запуск пленочной ракеты, эксперименты с карбидом и неуклюжий поцелуй - все это вершилось под ее провисшей с годами крышей» (Мишин 2014).

Эти элементы активно используются для общения жителей (практика сидеть на крыльце/веранде с соседями/гостями, говорить с балкона с соседями во дворе), социального контроля пространства (например, присмотра за играющими во дворе и на улице детьми). «На уличных крылечках сидели деревенского вида старушки, чье вечное оцепенение сменялось кратковременным оживлением при появлении молочника с громыхающими бидонами или татарина с леонардовского вида передвижным точильным кругом, издающего визгливое “точу ножи-ножницы”» (Мишин 2014).

Небольшое число жителей во дворе (зависит от размера двора и этажности застройки - в самарских дворах она преимущественно малоэтажная), сообщает жителям, что это пространство полуприватное, и в то же время общее. Его надо делить с соседями - договариваться с ними о правилах совместного использования. В постсоветский период число жителей во дворах уменьшилось из-за уменьшения числа коммунальных квартир. Фреймирование пространства как полуприватного делает резидентов готовыми договариваться о совместном благоустройстве, уборке двора, ремонте и реконструкции зданий, проведении инженерных коммуникаций и решении повседневных бытовых вопросов: «Мы с соседями помогаем друг другу - двор вместе убираем, зимой всей толпой снег чистим» (ПМА 2020, Андрей, 35 лет).

Проницаемость двора для «чужаков» не позволяет воспринимать его как закрытое пространство. Зачастую ворота во двор отсутствуют или не запираются (иногда только на ночь), и постороннему человеку легко попасть вовнутрь. Но его тут же замечают жители и вступают с ним в коммуникацию: «...Если зайдет кто-то просто посидеть, сразу скажут: ты чего парень, к кому ты пришел?» (ПМА 2020, Андрей, 35 лет). В тёплое время года жители оставляют открытыми двери квартир и мастерских; иногда соседи знают, где спрятаны ключи от квартир соседей. В последние годы проницаемость дворовых пространств стала уменышаться - всё больше дворов закрываются для посторонних.

Размер и форма двора, возможность его фрагментации, небольшое число жителей, возможность пристроек и малых архитектурных форм позволяют жителям идентифицировать двор как полуприватное пространство. Они «присваивают» себе фрагменты 
этого пространства, транслируя в них функции дома/квартиры. При этом один и тот же объект или фрагмент пространства (стол, скамейка, беседка, сарай, клумба, палисадник, парковка, маленький садик) может быть «присвоен» разными семьями одновременно - находиться в совместном пользовании, о котором они договорились.

В качестве пространства, обладающего полудеревенской (и полугородской) атмосферой жители фреймируют двор благодаря историческим зданиям и артефактам (старые деревянные сараи, руины, полуразрушенные, отдельно стоящие брандмауэры, старинные элементы декора домов, заброшенные сады), материалам и фактуре объектов (старое дерево, старый кирпич) (ПМА 2020, ПМА 2016).

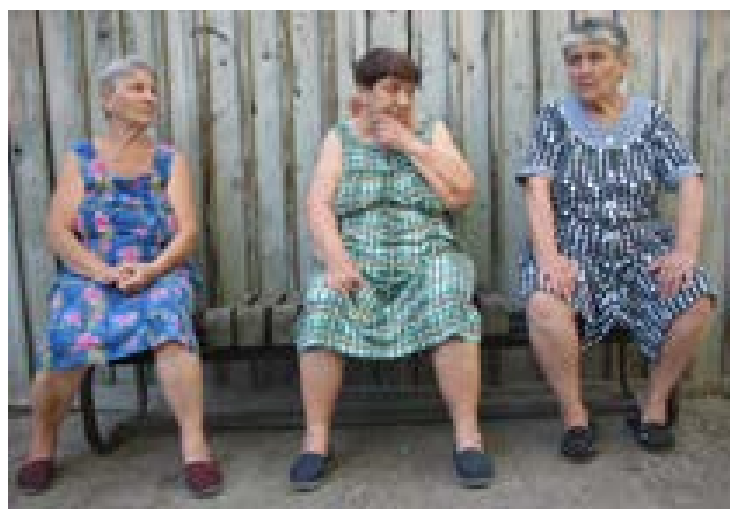

Рис. 4. Жители собираются на старых улочках города (фото автора, исторический иентр Самары, 2016).

Fig. 4. Locals gather out in the old streets of the city (photo by the author, the historical center of Samara, 2016).

Иногда жители объединяются и устраивают в помещениях и во двоpax мастерские, например, по ремонту машин, общаются, играют, пьют пиво, ухаживают за палисадниками, сажают цветы, овощи, ходят друг к другу в гости: «Ходим в гости друг к другу - это святое» (ПМА 2020, Наталья, 60 лет). В советское время во дворах выращивали овощи и зелень, ухаживали за фруктовыми садиками, оставшимися с дореволюционных времён (затем эта практика сошла на нет), разводили голубей. «Аллея приводила в изобильный старый вишневый сад. Изобильный настолько, что считалось особым шиком, лежа на теплой толевой крыше сарая, есть вишни без помощи рук, просто склевывая их со склонившихся от тяжести веток, а потом лихо выплевывая косточку» (Мишин 2014). Семьи, переехавшие из сёл, привозили с собой полудеревенский уклад: разводили под домами курятники, хранили в сенях деревенские припасы: «В город они переехали из села Похвистнево, но ментально переехали не до конца и потому у них царил полу-деревенский уклад: под нашим домом был устроен курятник, а по дому бегали цыплята» (Мишин 2014).

Такие практики частично сохраняются и сегодня. Жители совместно используют и строят дворовую инфраструктуру (парковочные места, площадки под барбекю, детские площадки, летние беседки); во двор выносят столы и стулья, они используются для общения с соседями и гостями (ПМА 2016). В советское время жители собирались во дворе вокруг почтальона, рассказывавшего о последних событиях: «Первый двор служил местом парадной жизни и коммуникаций с городом: сюда приходила тетенька-почтальон и раздавала корреспонденцию, одновременно рассказывая обитателям здешних лавочек об актуальных событиях [...] Сюда приезжала, грохочущая бидоном на тележке, молочница и заворачивал точильщик ножей» (Мишин 2014).

Многие люди вспоминают, что еще в 2000-е годы во дворе за общим столом отмечали все праздники: устраивали застолье, ставили самовар, ели пироги, пели, играли в домино, карты и крокет до глубокой ночи (игры проходили и в общих помещениях внутри домов), ставили спектакли с детьми. В советское время дети играли в вы- 
шибалу, чику и штандер, шахматы, карты, всем двором собирали сирень: «В оговоренный соседями весенний день все население двора собиралось на сбор сирени» (Мишин 2014). В последнее время эти практики исчезают - люди общаются меньше, «каждый живёт своей жизнью».

Жители связывают это со сменой поколений, и приходом новых жителей (но их ротация в старых кварталах очень небольшая): «В молодости хорошо было во дворе, соседи дружные были, за меня на суд свидетелями пошли 12 человек, но они все уже на том свете» (ПМА 2020, Надежда, 75 лет). «Во дворе сейчас не собираемся, как-то это все ушло. Раньше и пироги пекли, здесь ставили столы, все ели, это было прекрасно, это нужно видеть. Ну, это уже лет 8 назад, а сейчас новые люди» (ПМА 2020, Наталья, 60 лет). «Раньше в 2010 г. у кого-то день рождения - стол накрывали, даже вот когда дочка родилась, весь двор гудел. А так-то в советское время еще хлеще тут было. А сейчас все просто по своим делам» (ПМА 2020, Андрей, 35 лет).

В более дружных дворах дети и взрослые играют в бадминтон и футбол. Благодаря наличию старожилов резиденты ощущают связь с историей двора и реализуемыми в нём культурными практиками. Они продолжают традиции двора, передают их новым жителям, зачастую именно благодаря старожилам жители поддерживают практики взаимодействия. «И вот у этой дети уехали в Москву - они меня обнимают, я не знаю почему... Приезжают из Москвы и обнимают - как мы соскучились» (ПМА 2020, Наталья 60 лет). Многие жители строят планы на будущее по обустройству дворов и ремонту зданий.

Элементы «городской деревни» в старой Самаре можно встретить не только во двориках, но и на улицах. Уличная коммуникация осуществляется в условиях небольшой ширины улиц (до 25 м), достаточной ширине тротуаров (от 3 м) и слабого транспортного потока. Такую улицу жители идентифицируют как тихую, спокойную, как бы продолжающую двор. Ее используют как нейтральную территорию для встреч (случайных или намеренных). Жители собираются около своих домов (особенно имеющих выход на улицу), на уличных крылечках, лестницах, у входов в подъезды, около ворот - небольшими группами (по 2-4 человека) (ПМА 2016). Когда транспорта становится заметно больше, уличная жизнь для соседей прекращается, улица начинает выполнять только транзитную функцию.

В тёплое время года улицы используются детьми и подростками. Дети с одной улицы/квартала собираются вместе для игр, катаются на велосипедах, гуляют с собаками. На нешироких улицах с просторными тротуарами возникают получастные палисадники. Жители совместно благоустраивают общественные территории перед своим двором, изредка (по сравнению с советским временем) сооружают временные или постоянные места для сидения и общения. В постсоветский период практик уличного садоводства стало меньше, нередко городские власти срубают деревья и асфальтируют палисадники.

Таким образом, некоторые из сложившихся в советское время практик обитания во дворах и на улицах исторических центров воспроизводятся и в постсоветской Самаре, другие постепенно исчезают из-за разрушения границ и планировки дворов, сноса исторических зданий, строительства высотных зданий по соседству с историческими и утраты исторических «артефактов».

Наиболее важные маркеры пространства «городской деревни» - сравнительно небольшое количество жителей, размер и форма двора и квартала, возможность 
фрагментации границ (если утрачивается деление квартала на участки, пространство начинает восприниматься жителями как «ничейное», «необжитое» - их утрата неминуемо ведёт к рефреймированию «городской деревни». При значительном увеличении размера двора жителей рефреймируют двор как «отчужденное» пространство. В результате множество совместных практик освоения и обустройства пространства исчезают. То же самое происходит при резком увеличении этажности и числа жителей. Внутренняя жизнь во двориках исчезает уже при появлении высоток в соседних кварталах: из-за прокладки инженерной инфраструктуры для новостроек у старых домов рушатся стены и фундаменты, а территории дворов перекапываются. Жители начинают думать, что их квартал станет следующим под реновацию, и настраиваются на переезд: «Вот с весны рыли весь наш двор, теплотрассу меняли, подводят к новым домам, поэтому здесь уже не до уюта, временно так живём. А до этого цветы сажали и чай пили во дворе с соседями, а сейчас уже всё, на колесах все» (ПМА 2020, Надежда, 75 лет).

Факультативными маркерами можно считать наличие старожилов (их исчезновение затрудняет образование соседских сообществ, ведёт к атомизации и отчуждённости новых жителей, привыкших к таким практикам в микрорайонах). Это ведет к утрате социального капитала и преемственности культурных практик. При потере исторических зданий, артефактов, материалов и фактуры объектов дворы лишаются полудеревенской атмосферы. В них множество культурных практик жителей городской деревни становятся неуместными и невозможными. В то же время, как видно по современным малоэтажным кварталам иностранных городов, некоторые практики «городской деревни» там могут воспроизводиться.

Дополнительным маркером можно считать и возможность создания жителями собственных архитектурных элементов домов и дворов. Исчезновение такой возможности снижает желание проводить время во дворе и ощущение освоенности пространства (его сложнее маркировать как «свое»). В то же время дворовая жизнь возможна и в небольших дворах с современной застройкой, сделанных «под ключ».

Ключевой маркер, делающий возможным соседскую уличную жизнь в жилых районах - слабый поток транспорта. Облегчают ее возможность факультативные маркеры - ширина улиц и тротуаров. Культурные практики взаимодействия жителей на улицах поддерживаются только в случае, если внутри кварталов еще поддерживается «дворовая жизнь». Тогда улица становится продолжением двора. При утрате маркеров морфологии дворового пространства уличные практики также пропадают.

\section{Тбилиси}

Исторический центр Тбилиси обладает средневековой планировкой с хаотичными, тесными и кривыми улочками, переулками, тупиками и малоэтажной каменной застройкой с небольшими двориками. Беспорядочная плотная застройка возникала и на рубеже XVIII-XIX веков вокруг цитадели Нарикала (Анчабадзе, Волкова 1990). После вхождения Грузии в состав Российской империи, с начала XIX века, власть стала ограничивать беспорядочное строительство традиционных домов и «землянки», регулировать новую застройку и ремонт. Вокруг средневековой застройки Тифлиса стали появляться новые районы с регулярной планировкой, прямыми и широкими улицами, площадями, общественными зданиями европейской архитектуры 
разных стилей (Ольшевский 2003).

С увеличением числа жителей в начале XIX века, одноэтажные, углубленные в землю традиционные дома постепенно уплотнялись, надстраивались новыми этажами с крытыми галереями разной формы и конфигурации (Анчабадзе, Волкова 1990). В небольшом количестве дома с галереями встречались в конце XVIII века и имели плоскую кровлю. Старые здания заменялись новыми одноэтажными и двухэтажными, которые потом достраивались и имели дворовые пространства. Раньше дворов практически не было, их функ-

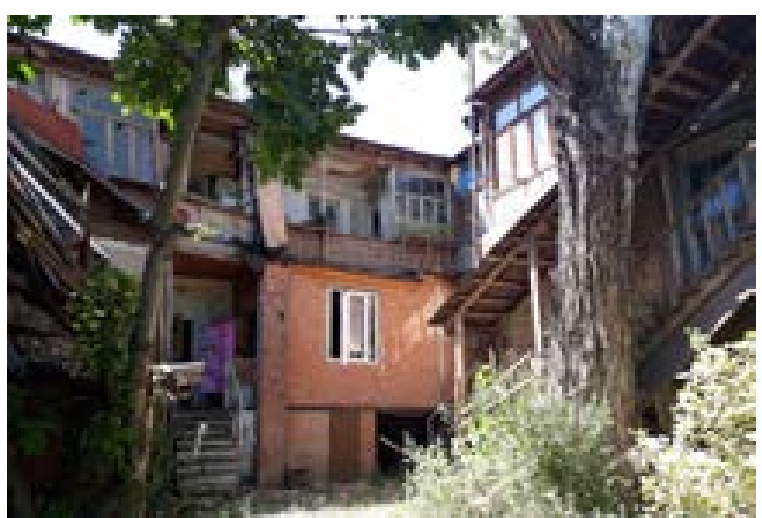

Рис. 5. Дворик в старом иентре Тбилиси (фото автора, старый центр Тбилиси, 2017).

Fig. 5. A courtyard in the old center of Tbilisi (photo by the author, old center of Tbilisi, 2017). ции выполняли плоские крыши. Первые этажи превращались в хозяйственные помещения, кладовые и конюшни, а во дворах строили флигели, кухни, пекарни, сараи, помещения для крупного рогатого скота, разводили фруктовые сады и огороды.

Развивался «полуевропейский» - «полуазиатский» тип зданий при сохранении средневековой планировки Старого города. Во второй половине XIX века дом с крытыми галереями занял ведущее место в городской застройке, а в начале XX века появились доходные дома - нередко 4-этажные. С приходом советской власти возникли коммунальные формы жизни. Такой тбилисский тип архитектурного пространства сохранился в советское и постсоветское время.

Основные маркеры современной морфологии тбилисских двориков (с их шумной, эмоциональной жизнью) - планировка кварталов (средневековая-хаотичная, в отдельных районах - регулярная), периметральная застройка высокой плотности (дворы плотно застроены по периметру и образуют замкнутое пространство), размер дворов - от самых узких (15х25) до более просторных (ширина 25/30/40 м., а глубина 30/40/50 м.), этажность - 2-5 этажей. Они формируют компактное, камерное пространство двора, которое фреймируется жителями и как полуприватное, полупубличное пространство (пограничное между квартирой и улицей), и как продолжение дома. Очень важны для тбилисских двориков архитектурные элементы домов. Фасады каменных зданий внутри двориков усыпаны ажурными деревянными балкончиками, застеклёнными и незастеклёнными галереями, открытыми террасами, которые объединяют несколько квартир, переплетающимися винтовыми лестницами с кованными ступенями на 3-5 этажей.

Жители фреймируют элементы пространства, продолжающие квартиры, перетекающие из дома во двор и связывающие их, как территории, где заканчивается частное и начинается пространство коммуникации с соседями. Значительная часть взаимодействий между обитателями проходит именно там - еще с XIX века крытые галереи стали местом отдыха и встреч с соседями и гостями. Такие элементы придают дворикам обжитость и атмосферность.

Перечисленные маркеры позволяют жителям идентифицировать пространство как «городскую деревню» и способствуют тесному контакту жителей, дают возможность 
общаться друг с другом, не выходя из дома. Существенная часть жизни жителей старого Тбилиси проходит на глазах соседей, а их дворы в сознании тбилисцев стали символом близких отношений (Захарова 2013). «Жизнь моей семьи была подключена к кровеносной системе города, с его многообразным, постоянным, ежедневным человеческим общением [...] День, когда к нам в дом не заходили бы родственники,

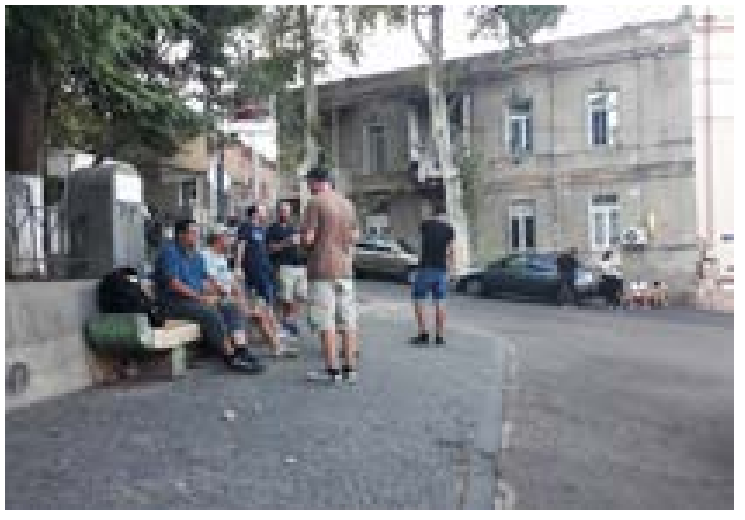

Pис. 6. «Corner societies» на улочках Тбилиси (фото автора, старый центр Тбилиси, 2017). Pic. 6. "Corner Societies" on the streets of Tbilisi (photo by the author, old center of Tbilisi, 2017). гости или соседи и стол накрывался только для членов семьи, мне трудно припомнить. Бабушка моя такого «чёрного дня» просто не вынесла бы» (Церетели 2017).

Крытая галерея взяла на себя часть его социальных функций, которые до второй половины XIX века выполняла плоская крыша, заменявшая двор (Анчабадзе, Волкова 1990). Галерея и балкон играли настолько важную роль, что иногда занимали большую площадь, чем комнаты: «Тбилисский балкон - это, по сути, летняя комната, где непременно присутствует удобная тахта, накрытая домотканым ковром; на нём мутаки - мягкие, удобные длинные валики, набитые овечьей шерстью; перед тахтой - стол» (Церетели 2017).

На балконах отдыхают, читают, спят, едят, пьют кофе, гладят, стирают, готовят варенье, общаются с соседями и прохожими, принимают гостей, выращивают цветы и небольшие растения, развешивают бельё, прогуливают детей, дерутся (Микаридзе 2019). Из окон, выходящих на галерею, наблюдают за тем, что происходит во дворе. Жители соседних домов могут общаться, стоя на разных балконах. В отличие от самарской, в тбилисской модели жители обживают не столько сам двор (особенно если он совсем мал по размеру), сколько балконы, галереи и террасы: именно эти элементы морфологии объединяют людей (ПМА 2017).

За пределами галерей и балконов тоже протекает совместная соседская жизнь. Дворы украшают выращенными в горшках растениями, ставят столы, за которыми мужчины устраивают застолья, играют до позднего вечера в нарды, домино, шахматы, волейбол (Микаридзе 2020). Во дворах часто что-то мастерят, дети с 5-6 лет играют во дворах и на улице одни, контролируемые взрослыми из окон (Захарова 2013): «Едва я научилась ходить и произносить первые слова, меня, как и каждого тбилисского ребенка, потянуло во двор [...] Самой устрашающей и самой действенной для нас, детей, была родительская угроза: «Всё! Во двор тебя сегодня не пущу!»» (Церетели 2017).

Тбилисский дворик - это театральная сцена, на которой всегда что-то происходит (Микаридзе 2019). Среди жителей распространены практики взаимопомощи и общие для всего двора традиции (Микаридзе 2018). «Делиться с соседями едой, будь то хоть кукурузная лепёшка, хоть тарелка супа [...] Скидываться на свадьбы, на похороны, дежурить, сменяя друг друга у постели больного родственника или соседа было для тбилисца внутренней потребностью, естественным и неоспоримым законом сосуществования. Отчуждённость, равнодушие, неспособность отзываться на радости и горести 
окружающих считались серьезным пороком личности - с бездушным человеком не стоит иметь дело, с ним лучше не связываться» (Церетели 2017). Иногда в двориках Тбилиси организуются концерты под открытым небом - в них набиваются зрители, а в дождь укрываются на балконах и под навесами (Микаридзе 2016).

Помогают взаимодействию обитателей тбилисских дворов наличие большого количества старожилов и небольшое число обитателей двора (в среднем 20-30 чел.). Первый маркер позволяет фреймировать тбилисский двор как место с историей, сложившимися культурными практиками, традициями и социальным капиталом, а второй сообщает, что это частно-публичное пространство. В силу малого размера и плотной периметральной застройки тбилисские дворы, в отличие от самарских, в меньшей степени допускают фрагментацию внутреннего пространства, но имеют более жесткие внешние границы. Эта же особенность позволяет резидентам воспринимать дворы как нечто преемственное и неизменное.

Для тбилисских двориков всегда была характерна прозрачность границ между публичным пространством (двор и улица) и приватным (дом, квартира); это становится и причиной, и следствием близости между соседями (Захарова 2013). Это позволяет жителям фреймировать двор как место, располагающее к публичной коммуникации и взаимодействию, и в то же время частное (например, хозяин может выйти во двор в нижнем белье). Дворы и подъезды в центре Тбилиси, как правило, открыты (ПМА 2017). Ночью люди даже на первых этажах спят с открытыми нараспашку окнами, выходящими прямо на улицу, и даже с незнакомцами разговаривают через открытую дверь.

В Тбилиси районы города называют «убани» (от слова «убе» - пазуха). Это «надежное, родное место совместного проживания (...) “за пазухой”» (Церетели 2017). Соседские сообщества на территории своего «убани» резиденты называют «большой семьей», в которой «все всех знают», а жизнь во дворах проходит «как на ладони» (Захарова 2013). Границы этих сообществ проводятся не столько по границам кварталов/улиц, сколько по линиям расселения представителей сообщества (там же). На это влияет хаотичная средневековая планировка.

В Тбилиси множество социальных интеракций между соседями происходит на улицах и в переулках. На улицах Тбилиси можно встретить сообщества, представители которых регулярно взаимодействуют в одном и том же месте («corner societies») (Whyte 1943). Этому способствует такой маркер физического пространства как ширина улиц (4-20 м.) и переулков (4-8 м). Жители мыслят улицу как продолжение двора. Обитатели соседних дворов могут часами стоять на улице, обычно рядом со своими домами, общаясь между собой и наблюдая за уличной жизнью. Она становится своеобразным продолжением общей галереи и балкона: «Вспоминаю, как папа, отправляясь на работу, всегда находил пару минут, чтобы бросить несколько приветственных фраз дворнику Алекси, чистильщику сапог Иско или справиться о здоровье у нашего уличного парикмахера» (Церетели 2017).

Такие же собрания часто возникают в скверах и парках, на скамейках и за длинными столами с навесом или беседкой. Сами жители сравнивают эти городские места со специально обустроенными в центре деревни или около воды точками сбора и общения деревенских жителей (Захарова 2013). Они играют в домино, шахматы, нарды, карты, могут устроить небольшое застолье с песнями: «Какое же может быть грузинское застолье без песен!» (Церетели 2017). Такое времяпрепровождение больше характерно для мужчин, тогда как женщинам чаще отводится приватное пространство 
(однако они ходят в гости друг к другу без приглашения - маркер «деревенского»).

Дворовая жизнь вырывается на улицу, когда обитатели домов из открытых окон общаются с прохожими и соседями, собирая вокруг себя целую группу собеседников, играют на улицах в шахматы и другие игры: «“Висеть” в окнах и эмоционально, во весь голос общаться с соседями по дому и улице, пожалуй, самый излюбленный вид досуга тбилисцев» (Церетели 2017). На территории своего «убани» считается нормой заговорить с незнакомцем; в местных магазинчиках соседи общаются с их владельцами и друг с другом. Часто такие магазины и кафе являются семейными и принадлежат людям, живущим в этих же домах (Захарова 2013). Продавцы знают по именам и в лицо жителей ближайших домов, дают в долг продукты и деньги. У духанщиков - хозяев духанов (кафе) в старых районах Чугурети и Кукии еще жива традиция встречать гостей словом «нисиа», выражающим доверие к простому человеку (Церетели 2017). «Нисиа - значит кушай досыта! Я тебе доверяю. Нет денег сегодня - занесешь позже, когда заработаешь» (там же).

Центр Тбилиси ценен не только необычной архитектурной средой, сочетающей европейскую и восточную культуру, но и присущими ей практиками социального взаимодействия жителей. В историческом центре Тбилиси, в сравнении с Самарой, гораздо меньше разрушений морфологии, пространство более целостное, хотя и там встречаются практики разрушительного строительства (Микаридзе 2017).

В Тбилиси, в силу «престижности» исторического центра, выкупают землю, разрушают старые и строят новые частные дома, сохраняя при этом этажность и размер участка. Однако превращение домов из многоквартирных в частные уменьшает число жителей, делает менее прозрачными границы между двором и улицей, сокращает практики соседского взаимодействия: жители старых домов реже контактируют с новыми жителями. Частный двор рефреймируется жителями соседних дворов как закрытое, отчужденное пространство.

Таким образом, размер участка и этажность застройки являются для тбилисских дворов факультативными маркерами: сохранение лишь этих параметров ведет к утрате дворовых культурных практик. Основными маркерами, позволяющими этим практикам сохраниться, являются достаточное число жителей, наличие старожилов и галерей, террас и балкончиков, объединяющих обитателей нескольких квартир. Без них жители фреймируют пространство как не располагающее к общению. При сносе старых домов, когда утрачивается плотная периметральная застройка, размер двора, его границы и архитектурные элементы, пространство рефреймируется жителями как общественное. Это ведет к утрате практик горизонтального взаимодействия и умения договариваться об условиях проживания в общем пространстве.

В уютных переулках и на улочках Тбилиси проходит значительная часть взаимодействий и общения между жителями. Мало- и среднеэтажное пространство, ширина улиц и переулков способствует их обживанию, в чем большую роль играют маленькие семейные магазинчики и другие сервисы, встроенные в жилые дома.

В отличии от морфологии микрорайонной застройки, исторические центры Тбилиси и Самары обладают маркерами, позволяющими фреймировать пространство дворов как частно-публичное, продолжающее дом/квартиру. Жители осмысляют двор как место коммуникации и взаимодействия, что обуславливает практики совместного времяпрепровождения и общения резидентов. При этом в самарских двориках больше приватных фрагментов пространств, а в тбилисских - публичных. 
Более свободное пространство самарских двориков располагает их жителей к совместной деятельности и благоустройству, дополнению пространства новыми функциями. Морфология тбилисских двориков скорее располагает к общению. Самарские дворы обладают атмосферой, которая ближе к деревенской, а тбилисские - к городской. В центре Тбилиси очень важную роль играют балконы и галереи, улицы и переулки, на которых происходит взаимодействие, а в Самаре квартальная жизнь сосредоточена во дворах. При этом оба этих пространство адекватнее всего описываются посредством концепта «городской деревни».

\section{Выводы}

В этой статье мы рассмотрели влияние различных маркеров морфологии городского пространства на социальные практики взаимодействия жителей исторических центров Самары и Тбилиси. Многие аспекты остались за рамками нашего анализа: конечно, на такие практики влияет культура, социально-политические и социально-экономические преобразования, социальный состав жителей этих районов, символическая ценность наследия для жителей города, жилищная политика властей и застройщиков, помощь городских властей в реставрации и ремонте наследия и множество других факторов. Но первое место среди них занимают маркеры городской морфологии, которые позволяют жителям тем или иным образом фреймировать окружающее их городское пространство.

В историческом центре Тбилиси, в сравнении с центром Самары, практики горизонтального взаимодействия между жителями с середины XX века не угасают, а продолжают существовать благодаря целостному сохранению городской морфологии. Разрушительные вторжения в историческую среду центра Самары ведут к ослаблению практик взаимодействия жителей (но сегодня они еще сохранены).

И в Тбилиси, и в Самаре дворы воспринимаются жителями как частно-публичное пространство - продолжение дома, присвоенное себе, но в то же время разделяемое с соседями. Самарский двор, особенно в постсоветское время, имеет больше признаков частного, индивидуального пространства. В него перемещаются функции дома, а некоторые образуются благодаря просторной территории (мастерские, детские площадки). Другие практики наследуются от привнесённого в советское время «деревенского» опыта (палисадники, огороды, разведение животных). На культурные практики влияет и оставшееся от прежних форм жизни в городских усадьбах физическое наследие: садики, сараи с погребами, сводчатые подвалы.

Фреймирование дворов как частно-публичных (а районов, в которые они входят - как «городской деревни») позволяет обитателям исторического центра Самары заниматься обустройством фрагментов своих дворов и домов, а жителям центра Тбилиси - проводить много времени, общаясь друг с другом. В полуприватных самарских двориках достаточно пространства и для индивидуального, и для совместного времяпрепровождения, а компактные тбилисские дворики более публичны, они становятся сценой повседневных взаимодействий соседей.

Такое фреймирование дворов и районов создает благоприятную среду для появления городских сообществ, основой которых являются старожилы. Морфология старых кварталов способствует объединению жителей, горизонтальным практикам взаимодействия между ними, возникновению навыков управления общим пространством. Несмотря на недостатки коммунального хозяйства, трудности с реставрацией 
исторических домов, ссоры среди соседей, а в случае Тбилиси - еще и сложности с уединением, многие обитатели исторических центров Тбилиси и Самары считают многоэтажки непригодными для проживания и не хотят покидать исторический центр. «Шикарно тут жить, ну какой там 15 микрорайон, одни девятиэтажки картонные, а тут свой быт, есть куда сходить, вот набережная» (ПМА 2020, Андрей, 36 лет). «Я бы рада здесь остаться, да не оставят» (ПМА 2020, Надежда, 75 лет). Думая о развитии этих городов, нельзя забывать об этом факторе, ведь его исчезновение лишит эти города их своеобразия и привлекательности.

\section{Благодарности}

Выражаю огромную благодарность Борису Грозовскому за ценные обсуждения статьи и чудесную редакторскую работу; Евгении Репиной и Сергею Малахову за оптики чтения исторических городов и пиетет к их внутренней жизни; Марии Васехе за стимул взглянуть на города с нового ракурса; жителям Самары и Тбилиси за вдохновение и красоту.

\section{Источники и материалы}

ПМА 2020 - Полевые материалы автора, Самара, август 2020 г.

ПМА 2016 - Полевые материалы автора, Самара, июль 2016 г. в рамках проекта регенерации квартала №13 в историческом центре Самары в составе исследовательской группы Института города Самары и Академии строительства и архитектуры (АСА СамГТУ).

ПМА 2017 - Полевые материалы автора, Тбилиси, август 2017 г.

\section{Научная литература}

Андреев Д. Вы хотите храм, мы хотим сквер - будет война // Meduza, 2019. Доступ: https://meduza. io/feature/2019/05/14/vy-hotite-hram-my-hotim-skver-budet-voyna (дата обращения: 18.01.2020).

Анчабадзе Ю.Д., Волкова Н.Г. Старый Тбилиси. Город и горожане в ХІХ веке. М.: Наука, 1990. 273 с.

Вахштайн B.C. Места большого города: К изучению социальной логики «Охотного Ряда» // Прогнозис, 2007. № 4. С. 4.

Гофман И. Анализ фреймов: эссе об организации повседневного опыта // пер. с англ., под ред. Г.С. Батыгина и Л.А. Козловой. М.: Институт социологии РАН, 2003. 752 с.

Джекобс Д. Смерть и жизнь больших американских городов / пер. с англ. М.: Новое издательство, 2011. $406 \mathrm{c}$.

Иванов П. Как благоустроить двор, несмотря на апатию жителей // The Village, 2014. Доступ: https://www.the-village.ru/people/experience/142707-troparevo_experiment (дата обращения: 01.02.2021).

Желнина А.А., Тыканова Е.В. Формальные и неформальные гражданские инфраструктуры: современные исследования городского локального активизма в россии // Журнал социологии и социальной антропологии, 2019. Т. 22. №1. С. 162-192. DOI: https://doi. org/10.31119/jssa.2019.22.1.8.

Захарова Е.Ю. Локальная солидарность: мужские квартальные биржи города Тбилиси как часть соседских сообществ // Кавказский город: потенциал этнокультурных связей в урбанистической среде, 2013. С. 246-289.

Захарова Е.Ю. Черный мацони: прагматика тбилисского уличного кодекса // Антропологический форум, 2016. № 31. С. 25-62.

Зукин Ш. Обнажённый город. Смерть и жизнь аутентичных городских пространств / пер. с англ. А.Лазарева и Н.Эдельмана; под науч. ред. В.Данилова. М.: Изд-во Института Гайдара, 2019. 360 с.

Кузнецова Е. Столичные митинги против реновации собрали в выходные 6 тыс. человек // РБК, 2017. Доступ: https://www.rbc.ru/politics/28/05/2017/592a87da9a794728587c03cd (дата обращения: 01.02.2021).

Лащенко С.В. «Городская деревня» («Urban village») как форма обитания в исторических центрах больших городов // Градостроительство и архитектура, 2020. Т. 10, № 3. С. 45-51. 
DOI:10.17673/Vestnik.2020.03.7.

Малахов C.A. Самарский двор - средовой и социокультурный феномен // Наследие под угрозой. Совместный отчёт SAVE и MAPS / под ред. В.Э. Стадникова. Самара: Издательский дом Агни, 2009. С. 60-66.

Медведев И.Р. Разрешение городских конфликтов. М.: Инфотропик Медиа, 2017. 372 с.

Микаридзе E. Кинематографическая архитектура Тбилиси: дом с инициалами, историями и формулой любви // SPUTNIK, 2020. Доступ: https://sputnik-georgia.ru/ columnists/20201218/250381654/Kinematograficheskaya-arkhitektura-dom-s-initsialamiistoriyami-i-formuloy-lyubvi.html (дата обращения: 28.01.2021).

Микаридзе Е. Тбилисские дворы - Грузия в миниатюре // SPUTNIK, 2016. Доступ: https:// sptnkne.ws/dUF5 (дата обращения: 28.01.2021).

Микаридзе Е. Если бы Тбилиси умел говорить // SPUTNIK, 2017. Доступ: https://sputnik-georgia. ru/Tbilisi/20170412/235575043/Esli-by-Tbilisi-umel-govorit.html (дата обращения: 31.01.2021).

Микаридзе Е. Тбилисские балконы и веранды - сцены из городской жизни // SPUTNIK, 2019. Доступ: https://sputnik-georgia.ru/columnists/20190718/245987452/Tbilisskie-balkony-iverandy-stseny-iz-gorodskoy-zhizni.html (дата обращения: 31.01.2021).

Микаридзе Е. Странности старого Тбилиси - для тех, кто не перестал удивляться // SPUTNIK, 2019. Доступ: https://sputnik-georgia.ru/columnists/20190425/245050842/Strannosti-starogoTbilisi-dlya-tekh-kto-ne-perestal-udivlyatsya.html (дата обращения: 01.02.2021).

Микаридзе E. Вахтанг Кикабидзе и традиции сололакского двора // SPUTNIK, 2018. Доступ: https://sputnik-georgia.ru/columnists/20181004/242331780/vakhtang-kikabidze-tradiciisololakskogo-dvora.html (дата обращения: 01.02.2021).

Ольшевский М.Я. Кавказ с 1841 по 1866 год. СПб.: Изд-во журнала «Звезда», 2003. 606 с.

Панеях Э.Л. Отмирание государства. Российское общество между постмодерном и архаикой // INLIBERTY, 2018. Доступ: https://www.inliberty.ru/article/modern-paneyakh/ (дата обращения: 18.01.2021).

Периев А. Мы съели повышение пенсионного возраста. А помойку проглотить не смогли» Как Архангельск превратился в центр массовых протестов // Meduza, 2019. Доступ: https://meduza.io/feature/2019/04/12/my-s-eli-povyshenie-pensionnogo-vozrasta-a-pomoykuproglotit-ne-smogli (дата обращения: 18.01.2021).

Реген E. Как устроены онлайн-сообщества соседей в Петербурге и какие проблемы в них решают жители района? Рассказывает социолог // Бумага, 2019. Доступ: https://paperpaper. ru/photos/kak-ustroeny-onlajn-soobshestva-sosed/ (дата обращения 25.01.2021).

Мишин С. Пост-проект самарского двора архитектора Сергея Мишина: город, двор, дом, мальчик // Другой город, 2014. Доступ: https://drugoigorod.ru/postproject/ (дата обращения 28.01.2021).

Церетели К. «Мне Тифлис горбатый снится..». М.: Искусство-ХХІ век, 2017. 272 с.

Яноу Д., Ван Хульст М. Фреймы политического: от фрейм-анализа к анализу фреймирования // Социологическое обозрение, 2011. Т. 10. №1-2. С. 87-113.

Blumer H. Symbolic interaction: perspective and method. Englewood Cliffs: Prentice-Hall, 1969

Gans H. The Urban Villagers: Group and Class in the Life of Italian-Americans. New York: Free Press, 1962. $367 \mathrm{p}$.

Mirmoghtadaee, M. A Proposed Method for the Analysis of Urban Character // Journal of Environmental Studies, 2006. №32. P. 129-140.

Larkham P. The Importance of Observation: Urban Morphology in the Field // Oliveira V. Teaching Urban Morphology. Switzerland: Springer, 2018. P. 265-279.

Nissen S. Urban transformation from public and private space to spaces of hybrid character // Sociologický časopis. 2008. Vol. 44, № 6. P. 1129-1150. DOI: 10.13060/00380288.2008.44.6.04.

Oliveira $V$. Urban morphology. An introduction to study of the physical form of the cities. Switzerland: Springer, 2016. 192 p.

Sadeghi G., Li B. Urban Morphology: Comparative Study of Different Schools of Thought// Current Urban Studies. 2019. № 7. P. 562-572. DOI: 10.4236/cus.2019.74029. 
Schiemann J., Weyers O., Araripe Rand L., Repina E., Malakhov S., Gnilomedov A. The Samarsky Yard. Yekaterinburg: TATLIN, 2020. 448 p.

Vihavainen R. Homeowners' Associations in Russia after the 2005 Housing Reform. Helsinki: Gummerus Printing, 2009. 274 p.

Whyte W. Street Corner Society. Chicago: The University of Chicago Press, 1943. 398 p.

\section{References}

Anchabadze, Yu. D., Volkova, N.G. 1990. Staryi Tbilisi. Gorod i gorozhane v XIX veke [Old Tbilisi. The city and its citizens in the XIX century]. Moscow: Nauka.

Andreev, D. 2019. Vy khotite khram, my khotim skver - budet voina [You want a temple, we want a square - there will be a war]. Meduza. https://meduza.io/feature/2019/05/14/vy-hotite-hrammy-hotim-skver-budet-voyna.

Blumer, H. 1969. Symbolic interaction: perspective and method. Englewood Cliffs: Prentice-Hall. Ivanov, P. 2014. Kak blagoustroit' dvor, nesmotria na apatiiu zhitelei [How to improve the yard, despite the apathy of the residents]. The Village. https://www.the-village.ru/people/ experience/142707-troparevo_experiment

Gans, H. 1962. The Urban Villagers: Group and Class in the Life of Italian-Americans. New York: Free Press.

Goffman, E. 2003. [Frame analysis: an essay on the organization of experience]. Moscow: Institut sotsiologii RAN.

Jacobs, J. 1961 (2011). Smert'i zhizn' bol'shikh amerikanskikh gorodov. [The Death and Life of Great American Cities]. Moscow: Novoe izdatel'stvo.

Kuznetsova, E. 2017. Stolichnye mitingi protiv renovatsii sobrali v vykhodnye 6 tys. Chelovek [The capital's rallies against the renovation gathered 6 thousand people over the weekend]. $R B K$. https://www.rbc.ru/politics/28/05/2017/592a87da9a794728587c03cd.

Lashchenko, S.V. 2020. “Gorodskaia derevnia” (“Urban village”) kak forma obitaniia v istoricheskikh tsentrakh bol'shikh gorodov ["City Village" as a form of habitation in the historical centers of large cities]. Gradostroitel'stvo i arkhitektura, Vol. 10 (3), 45-51. DOI:10.17673/Vestnik.2020.03.7.

Malakhov, S.A. 2009. Samarskii dvor - sredovoi i sotsiokul'turnyi fenomen [Samara's Yard -environmental and socio-cultural phenomenon]. Nasledie pod ugrozoi. Sovmestnyi otchet SAVE i MAPS, 60-66. Samara: Izdatel'skii dom Agni.

Medvedev, I.R. 2017. Razreshenie gorodskikh konfliktov [Urban conflict resolution]. Moscow: Infotropik Media.

Mikaridze, E. 2017. Esli by Tbilisi umel govorit' [If only Tbilisi could speak]. SPUTNIK. https:// sputnik-georgia.ru/Tbilisi/20170412/235575043/Esli-by-Tbilisi-umel-govorit.html.

Mikaridze, E. 2020. Kinematograficheskaia arkhitektura Tbilisi: dom s initsialami, istoriiami i formuloi liubvi [Cinematic architecture of Tbilisi: a house with initials, stories, and a love formula]. SPUTNIK. https://sputnik-georgia.ru/columnists/20201218/250381654/ Kinematograficheskaya-arkhitektura-dom-s-initsialami-istoriyami-i-formuloy-lyubvi.html.

Mikaridze, E. 2019. Strannosti starogo Tbilisi - dlia tekh, kto ne perestal udivliat'sia [The oddities of old Tbilisi-for those who have not ceased to be surprised]. SPUTNIK. https://sputnik-georgia.ru/ columnists/20190425/245050842/Strannosti-starogo-Tbilisi-dlya-tekh-kto-ne-perestal-udivlyatsya.html.

Mikaridze, E. 2019. Tbilisskie balkony i verandy - stseny iz gorodskoi zhizni [Tbilisi balconies and verandas-scenes from city life]. SPUTNIK. https://sputnik-georgia.ru/ columnists/20190718/245987452/Tbilisskie-balkony-i-verandy-stseny-iz-gorodskoy-zhizni.html.

Mikaridze, E. 2016. Tbilisskie dvory - Gruziia v miniatiure [Tbilisi Courtyards - Georgia in miniature]. SPUTNIK. https://sptnkne.ws/dUF5.

Mikaridze, E. 2018. Vakhtang Kikabidze i traditsii sololakskogo dvora [Vakhtang Kikabidze and the traditions of the Sololak court]. SPUTNIK. https://sputnik-georgia.ru/ columnists/20181004/242331780/vakhtang-kikabidze-tradicii-sololakskogo-dvora.html.

Mirmoghtadaee, M. 2006. A Proposed Method for the Analysis of Urban Character. Journal of 
Environmental Studies 32: 129-140.

Mishin, S. 2014. Post-proekt samarskogo dvora arkhitektora Sergeia Mishina: gorod, dvor, dom, mal'chik [Post-project of the Samara yard by architect Sergey Mishin: city, yard, house, boy]. Drugoi gorod. https://drugoigorod.ru/postproject/.

Larkham, P. 2018. The Importance of Observation: Urban Morphology in the Field. Oliveira V. Teaching Urban Morphology, 265-279. Switzerland: Springer.

Nissen, S. 2008. Urban transformation from public and private space to spaces of hybrid character. Sociologický časopis 44 (6): 1129-1150. DOI: 10.13060/00380288.2008.44.6.04.

Oliveira, V. 2016. Urban morphology. An introduction to study of the physical form of the cities. Switzerland: Springer.

Ol'shevskii, M.Ya. 2003. Kavkaz s 1841 po 1866 god [Caucasus from 1841 to 1866.]. St. Petersburg: Izdatel'stvo zhurnala 'Zvezda'.

Paneiakh, E.L. 2018. Otmiranie gosudarstva. Rossiiskoe obshchestvo mezhdu postmodernom i arkhaikoi [The withering away of the State. Russian society between postmodern and archaic]. INLIBERTY. https://www.inliberty.ru/article/modern-paneyakh/.

Pertsev, A. 2019. My s"eli povyshenie pensionnogo vozrasta. A pomoiku proglotit' ne smogli' Kak Arkhangel'sk prevratilsia v tsentr massovykh protestov [We ate up the retirement age increase. And they could not swallow the garbage " How Arkhangelsk turned into the center of mass protests]. Meduza. https://meduza.io/feature/2019/04/12/my-s-eli-povyshenie-pensionnogovozrasta-a-pomoyku-proglotit-ne-smogli.

Regen, E. 2019. Kak ustroeny onlain-soobshchestva sosedei v Peterburge i kakie problemy v nikh reshaiut zhiteli raiona? Rasskazyvaet sotsiolog [How do online communities of neighbors work in St. Petersburg and what problems do the residents of the district solve in them? Says the sociologist]. Bumaga. https://paperpaper.ru/photos/kak-ustroeny-onlajn-soobshestva-sosed/.

Sadeghi, G., Li, B. 2019. Urban Morphology: Comparative Study of Different Schools of Thought. Current Urban Studies 7: 562-572. DOI: 10.4236/cus.2019.74029.

Schiemann, J., Weyers, O., Araripe Rand, L., Repina, E., Malakhov, S., Gnilomedov, A. 2020. The Samarsky Yard. Yekaterinburg: TATLIN.

Tsereteli, K. 2017. "Mne Tiflis gorbatyi snitsia...” ["I dream of Tiflis the humpback...”]. Moscow: Iskusstvo-XXI vek.

Vakhshtain, V.S. 2007. Mesta bol'shogo goroda: K izucheniiu sotsial'noi logiki “Okhotnogo Riada" [Places of the Big City: To Study the Social Logic of "Okhotny Ryad"]. Prognozis. 4: 4.

Vihavainen, R. 2009. Homeowners' Associations in Russia after the 2005 Housing Reform. Helsinki: Gummerus Printing.

Whyte, W. 1943. Street Corner Society. Chicago: The University of Chicago Press.

Yanou, D., Van Khul'st, M. 2011. Freimy politicheskogo: ot freim-analiza k analizu freimirovaniia [Political frames: from frame analysis to framing analysis]. Sotsiologicheskoe obozrenie 10 (1-2): 87-113.

Zakharova, E.Yu. 2013. Lokal'naia solidarnost': muzhskie kvartal'nye birzhi goroda Tbilisi kak chast' sosedskikh soobshchestv [Local Solidarity: Men's neighborhood Exchanges in Tbilisi as part of neighborhood communities]. Kavkazskii gorod: potentsial etnokul'turnykh sviazei $v$ urbanisticheskoi srede, 246-289.

Zhelnina, A.A., Tykanova, E.V. 2019. Formal'nye i neformal'nye grazhdanskie infrastruktury: sovremennye issledovaniia gorodskogo lokal'nogo aktivizma v Rossii [Formal and informal civil infrastructures: modern studies of urban local activism in Russia]. Zhurnal sotsiologii $i$ sotsial'noi antropologii 22 (1): 162-192. DOI: https://doi.org/10.31119/jssa.2019.22.1.8.

Zukin, Sh. 2009 (2019). Obnazhennyi gorod. Smert' i zhizn' autentichnykh gorodskikh prostranstv [Naked City: The Death and Life of Authentic Urban Places] Moscow: Izdatel'stvo Instituta Gaidara. 